\title{
Scenario of arthropod diversity in organic farming system
}

\author{
Subash Singh
}

School of Organic Farming, Punjab Agricultural University, Ludhiana (Punjab) India

\section{ARITCLE INFO}

Received : 03.02 .2020

Accepted : 28.03 .2020

\section{KEY WORDS :}

Organic farming system, Conventional farming system, Arthropod diversity,

Predatory fauna, Species richness

*Corresponding author:

Email : subashsingh@pau.edu

\begin{abstract}
Major reasons of loss of arthropod diversity, species richness, dominance and abundance are due to the application of synthetic pesticides, deforestation for conventional farming and lack of habitat and microclimate, and all these occur under conventional farming system. A detailed review revealed the organic farming system to have an holistic approach in performing better than the conventional farming system as former provided important advantages like harmless chemicals, safety to human and animal health, species richness, abundance of insect predators and the pollinators.
\end{abstract}

How to view point the article : Singh, Subash (2020). Scenario of arthropod diversity in organic farming system. Internat. J. Plant Protec., 13(1) : 111-118, DOI : 10.15740/HAS/IJPP/13.1/111118, Copyright@ 2020: Hind Agri-Horticultural Society. 